\title{
The Effects of Activity and Gain Based Virtual Material on Student's Success, Permanency and Attitudes towards Science Lesson
}

\author{
Erol Taş \\ Correspondence: Erol Taş Science Education Program, Faculty of Education, Ordu University, 52200 Ordu, Turkey
}

Received: May 13, 2015 Accepted: June 1, $2015 \quad$ Online Published: July 27, 2015

doi:10.1114/jets.v3i5.817 URL: http://dx.doi.org/10.11114/jets.v3i5.817

\begin{abstract}
The main objective of this study is to research the effects of a student gains and activity based virtual material on students' success, permanence and attitudes towards science lesson, developed for science and technology lesson 6th grade "Systems in our body" unit. The study, which had a quasi-experimental design, was conducted with the participation of a total of 70 6th graders in a primary school. Before the study, a virtual material was developed by research which consisted of interactive activities for each of students' gains of the unit. In the experimental group, the virtual material was used by the teacher while teaching the unit. The Unit was treated in the usual way in the control group during the study. Achievement test, permanence test and science and technology lesson attitude scales were used as data collection tools and they were conducted on both groups as pre-test and post-test. SPSS 17 package program was used in the analysis of the data. As a conclusion, a significant difference in favor of the experimental group was found in students' achievement. But, it was not seen that virtual material based on activity and gain affected permanency in a positive way. Also, no statistically significant difference was found between groups as to students' achievement. In addition, when the attitudes of experimental and control group students towards the lesson after the study were examined, no statistically significant difference was found in post-test and permanency tests.
\end{abstract}

Keywords: Web assisted science education, achievement, permanency and attitude

\section{Introduction}

In order to be able to turn individuals into effective learners, traditional teaching perspectives in schools should be abandoned and innovative teaching attitudes should be adopted. Within this context, in order to be able to attract learners to the activity of learning, teaching activities which support learning through material designing process and which prioritize mutual interaction should be used (Liao \& She, 2009). Turkish science curriculum was renewed and modified radically according to the requirements of the current age and community's needs. The renewed curriculum was developed in terms of the main philosophy of the constructivist learning and multiple intelligent theories (Birgin and Çatlıoğlu, 2004; şahin, 2007). In the renewed curriculum, learning-teaching processes have been quite affected from these theories. Science topics and activities were designed according to these theories. It has been stated by researchers that there is a positive interaction between constructivist learning theory and technology (Hennessy et al., 2007; Taş \& Çepni, 2011). Apart from the program of science and technology teaching as main written source material, the use of technology has been emphasized in teaching subjects and concepts (MEB, 2006).

Many studies have been implemented about the influences of virtual materials on students attitudes are not agree whether it makes positive changes in attitudes towards science and science lessons. (Francisa, Katzb, Susan, \& Jonesc,

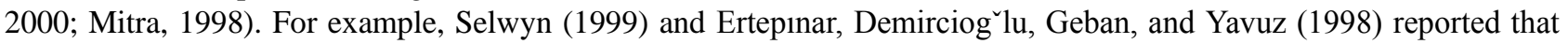
virtual materials develops a positive attitude towards science education. In contrast to this Shaw and Marlow (1999) said that CAIM do not show a positive effect on students' attitudes. Besides, students' attitudes towards science are quite negative if traditional teaching methods are used in science classes (Colletta \&Chiappetta, 1989).

Web assisted learning environment on constructivist theory has a foundation on which students learn by themselves and build knowledge in a way that is meaningful to them. Web assisted learning has also been found to have a positive effect on students' success (Jang, 2009). Use of web assisted learning in order to increase efficiency and ensure meaningful learning in science education, use of web assisted teaching has been recommended by researchers (Amadieu, Tricot, \& Mariné, 2010; Barak \& Dori, 2011; Bilgi \& Şahin, 2012; Erümit Fiş, 2013; Tas, 2011; Taş, Apaydın, \& Çetinkaya, 2011; Taş \& Çepni, 2011; Yu, She, \& Lee, 2010). For science education to make a difference in a student's 
life, it should take place through a student's experiences in his/her daily life. This way, environments that allow students to build knowledge through exploration should be formed. As a tool that helps students to present what they learn through web and to develop the design of the subjects debated, use of web assisted teaching has come to the forefront (Jang, 2009). When compared with classical materials, web-assisted materials developed for science and technology lesson give students more opportunities to learn by doing and to use their mental skills (Hickey, Ingram-Goble, \& Jameson, 2009). As well as teaching abstract subjects that the students have difficulty in comprehending through classical teaching methods, using web assisted activities developed about the subject can make learning more concrete and permanent (Barak \& Dori, 2011).

At the heart of constructivist theory, web assisted materials are needed that integrate field education and technology effectively. Teaching environments dynamized by animations and simulations regardless of limitations of time and space can carry education to every environment outside the classroom that has computer in it. Lesson materials which are developed by taking into consideration such conditions and needs will be effective resources for teachers and students. Web assisted lessons materials which are used by teachers during the lesson and by students after lesson will bring positive effects to learning (Kunduz \& Seçken, 2013). In addition, virtual materials should be developed in order to resolve negations such as lack of equipment, limited class hours, expensive lesson materials, and insufficient time for experiments in the curriculum (Kunduz \& Seçken, 2013).

Biological topics are located in secondary curricula from the beginning of Life Studies Curriculum in Turkey. They are widely used in Turkish Science and Technology Curriculum (TSTC) from fourth to eighth grade at each level (Çeken, 2012). The Unit "Systems in our body" is very significant to understand biology issues in both 6th And 7th Grades in secondary schools. The basic concepts of this unit are taught at main level in fourth and fifth grades. Also, the same unit is taught in 7th grade next year. It contains some important systems such as respiration, circulation, muscular and bone system. Circulatory system carries oxygen and nutrients from food to all the parts of the body. Then waste products like carbon dioxide are carried back out. Respiration is the process of releasing energy from the breakdown of glucose. It takes place in every living cell, all of the time and all cells need to respire in order to produce the energy that they require. The muscular system is the series of muscles throughout the body that moves the skeleton, maintains posture through steady contraction, and generates heat through cell metabolism. The skeletal system includes all of the bones and joints in the body. Each bone is a complex living organ that is made up of many cells, protein fibers, and minerals. The skeleton acts as a scaffold by providing support and protection for the soft tissues that make up the rest of the body.

The objective of our study is to research the effectiveness of an activity and gain based virtual material on students' science success and attitudes towards science lessons developed for the unit "Systems in our body", which is a unit of the 6th grade science and technology lesson.

\section{Material and Method}

A gain and activity based virtual material for the "systems in our body" unit of 6th grade science and technology lesson based on constructivist learning theory was developed by the researchers. Quasi-experimental research method was chosen to examine the effects of this material on students.

The study was performed with the participation of a total of 70 6th graders in a secondary school in the city center of Samsun during the academic year 2013-2014 and 37 of the students were female while 33 were male. Of the two different classes, one was assigned as the experimental group $(n=35)$ with random assignment while the other was assigned as the control group $(\mathrm{n}=35)$. In order to find out whether the experimental and control group students were matching in terms of the characteristics researched, Concept Achievement Test and Science and Technology lesson attitude test were administered before the study. Kolmogorov-Smirnov test and Levene test were applied on the data obtained. The results showed that the data was homogenous and had a normal distribution. Thus, since two groups within a universe were being studies, parametric independent t-test was applied. At the end of the study, the same tests were administered on the sample again as post-test and they were administered again as permanency and permanency test following a three weeks of time after the unit ended. The data obtained was compared by using $\mathrm{t}$ test for independent groups. In order to determine the association between the students' achievements and their attitudes, correlation analysis was made for the post-test data obtained from the attitude scale towards science and technology lesson and the achievement test.

Data collection tools which were analyzed for validity and reliability were used in this study. These are Academic Achievement Test and Attitude Scale for Science and Technology lesson. Academic Achievement Test was developed to find out the achievements of students on attainment. In order to provide the test's validity, a table of gains was prepared for the attainments predicted for the unit (Table 1). A multiple choice test consisting of 25 items were grouped into the three levels of the cognitive domain (understand, apply and analyze) of revised bloom's taxonomy and the data 
collection tool was finalized by taking the views of experts in the field. Thus, content validity was provided.

Table 1. The gains table including Systems in our body unit / Cognitive process aspect

\begin{tabular}{|c|c|c|c|c|c|c|c|}
\hline \multirow{2}{*}{ Unit Topics } & \multicolumn{7}{|c|}{ Gain distributions according to revised bloom's taxonomy } \\
\hline & remember & understand & apply & analyze & evaluate & create & Total \\
\hline Support and & & & & & & & \\
\hline $\begin{array}{l}\text { Movement } \\
\text { System }\end{array}$ & - & 4 & - & 2 & 1 & - & 7 \\
\hline $\begin{array}{l}\text { Respiratory } \\
\text { System }\end{array}$ & - & 6 & 1 & 3 & - & - & 10 \\
\hline $\begin{array}{l}\text { Fight with } \\
\text { Microorganisms }\end{array}$ & - & 5 & - & - & - & - & 5 \\
\hline $\begin{array}{l}\text { Respiration } \\
\text { System }\end{array}$ & - & - & 1 & 2 & 1 & 1 & 5 \\
\hline Total & - & 15 & 2 & 7 & 2 & 1 & 27 \\
\hline Percent $\%$ & - & $\% 56$ & $\% 7$ & $\% 26$ & $\% 7$ & $\% 4$ & $\% 100$ \\
\hline
\end{tabular}

A pilot study before the study was administered first. With the help of the data obtained from the pilot, the reliability coefficient of the test by using KR-20 was found to be 0.739. Attitude Scale for Science and Technology lesson was used to examine the students' attitudes towards Science and Technology lesson. Experts' views were taken for the content validity of the scale. Views and recommendations of two academics from Ondokuz Mayıs University, Faculty of Education, Department of Primary Science Education and also 3 science and education teachers were taken. The items which were formed by expert views were treaten on 30 secondary school students and the students were asked about the items they had difficulty in understanding. Such items were found and necessary edits were made. The 30 students who participated in the pilot of the scale were not included in the study group. This attitude scale was 5 Likert scale and it had 27 items after the pilot. the attitude scale was given to 357 students and the data obtained was analyzed with SPSS 17.0 package program and the reliability coefficient of the scale was found to be 0.919 cronbach- $\alpha$ value.

Principles and strategies adopted by constructivist learning theory were used in the design of the web material we prepared. Adobe Flash CS6 program was used to prepare the material and Adobe Dreamweaver CS6 web edit was used for web. With the material prepared, activities suitable for the unit "systems in our body" were developed (Figure 1)

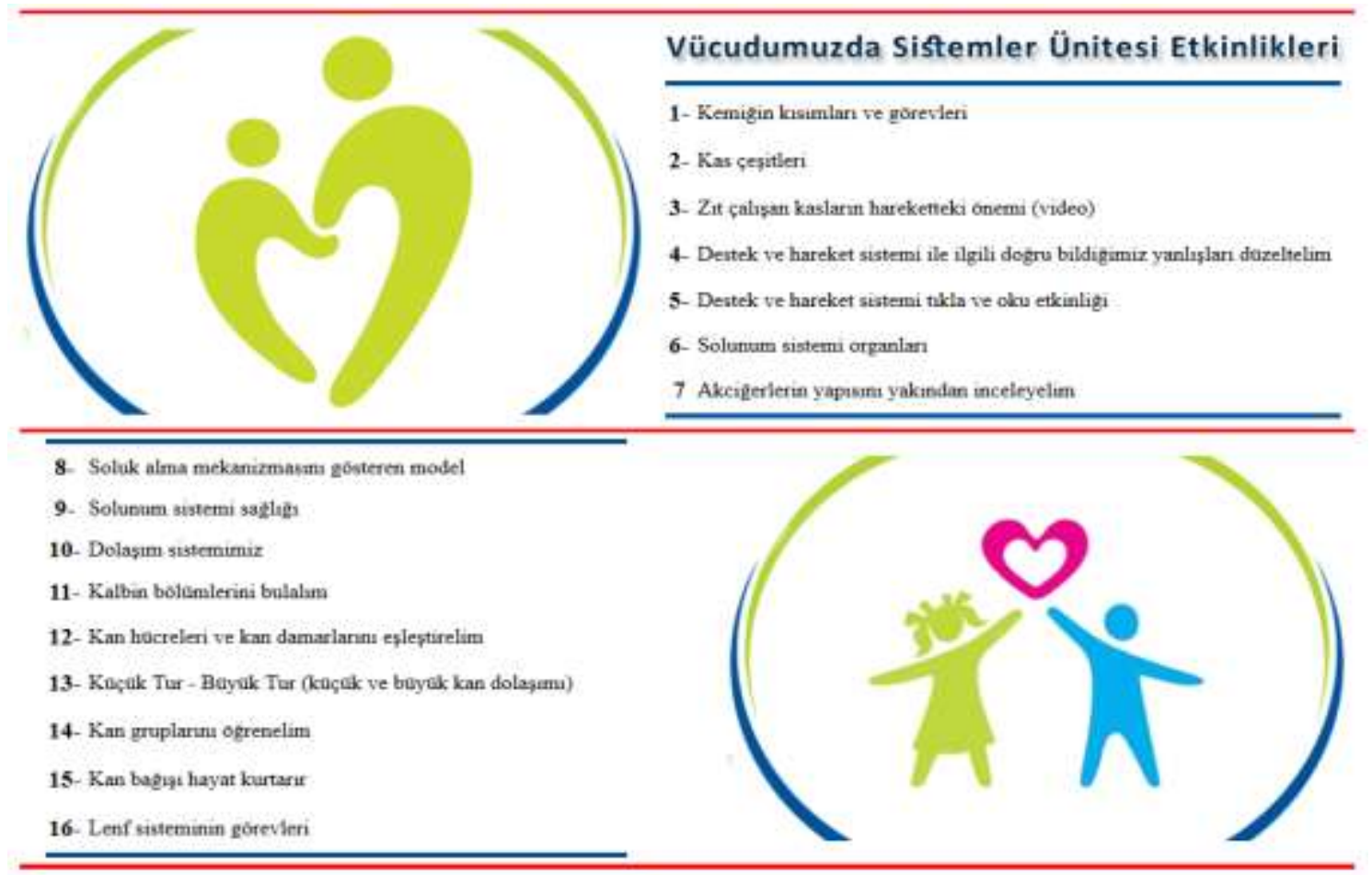

Figure 1. Outlook from the interface of "Web Assisted Activities" material.

While forming the activities used in the material, the activities in the textbook were considered and similar or alternative activities were used. All the activities that were prepared were formed in a way that students could use interactively. The contents of 27 gains of the unit were semantic feature analysis, conceptual maps, structured grid, 
association of words, video and animations (Figure 2). Students can both do the web assisted activities in class with the teacher; they can also repeat them as many times as they want by themselves.

\section{VÜCUDUMUZDA SISTEMLER ÜNITESI}

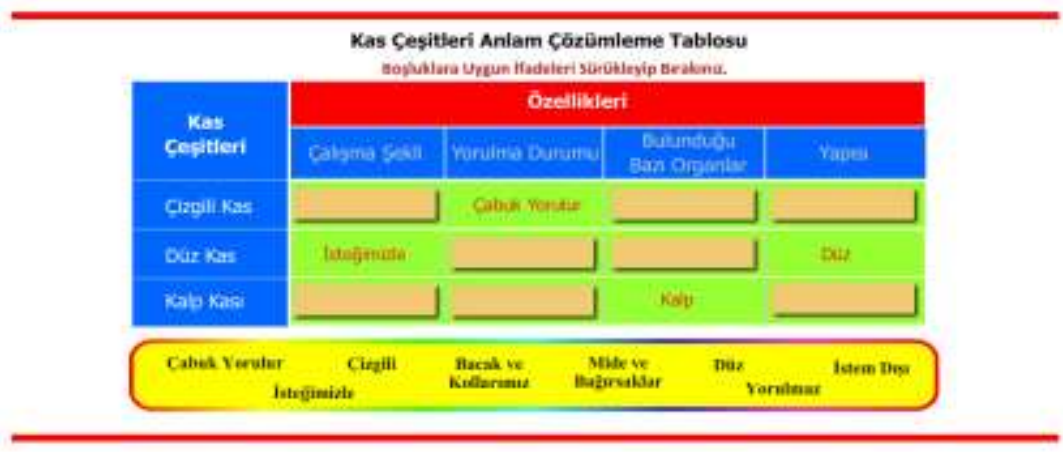

Figrue 2. "Semantic feature analysis related with types of muscle", an activity from the material.

\section{Findings}

In order to examine the effect of web assisted activity prepared for the teaching of "systems in our body" unit; pre-test, post-test and permanency test results of the academic achievement test administered to students and the comparison of these results in experimental and control groups were examined. In addition, the effects of achievement and activity based virtual material prepared for the teaching of "systems in our body" unit on the attitudes of students' attitudes towards science and technology lesson and the association between achievement and attitudes were examined.

\subsection{Achievement Test}

The results of the pre-test, post-test and permanency test which were treated to measure the experimental and control group students' achievements on the systems in our body unit are as follows.

Pre-test and post-test results of experimental and control groups are as follows.

Table 2. t-test results of the pre-test, post-test achievement scores of experimental and control groups

\begin{tabular}{ccccccc}
\hline Tests & Groups & $\begin{array}{c}\text { Number of } \\
\text { Students }\end{array}$ & Meaans & $\begin{array}{c}\text { Standard } \\
\text { Deviation }\end{array}$ & $\begin{array}{c}\text { t-test } \\
\text { results }\end{array}$ & Significance \\
\hline \multirow{3}{*}{ Pre-test } & EG & 35 & 42,6286 & 10,17230 & &, 460 \\
& CG & 35 & 41,3714 & 12,57235 & &, 647 \\
\multirow{2}{*}{ Post-test } & EG & 35 & 71,8857 & 14,07495 & & \\
& CG & 35 & 57,6000 & 12,20222 & &, 000 \\
\hline
\end{tabular}

\section{$\mathrm{P}<0.05$}

In Table 2, pre-test and post-test results of experimental and control groups were compared. No statistically significant difference was seen in the pre-test results of the groups $\left(\mathrm{t}_{(69)}=0.460, \mathrm{p}>0.05\right)$. This result showed that experimental and control group students are similar in terms of the researched characteristic. A statistically significant difference was seen between experimental and control groups in the post-test results $\left(\mathrm{t}_{(69)}=4,537, \mathrm{p}<0.05\right)$. This result showed a significant difference in favor of experimental group students in terms of achievement. Pre-test and post-test results of experimental and control groups within their own groups are as follows.

Table 3. T-test results of the pre-test, post-test achievement scores of experimental and control groups within their own groups

\begin{tabular}{|c|c|c|c|c|c|c|}
\hline Tests & Groups & $\begin{array}{l}\text { Number of } \\
\text { Students }\end{array}$ & Meaans & $\begin{array}{l}\text { Standard } \\
\text { Deviation }\end{array}$ & t-test results & Significance \\
\hline Pre-test & $\begin{array}{l}\text { EG } \\
\text { CG }\end{array}$ & $\begin{array}{l}35 \\
35\end{array}$ & $\begin{array}{l}42,6286 \\
71,8857\end{array}$ & $\begin{array}{l}10,17230 \\
14,07495\end{array}$ & $-9,967$ & ,000 \\
\hline Post-test & $\begin{array}{l}\text { EG } \\
\text { CG }\end{array}$ & $\begin{array}{l}35 \\
35\end{array}$ & $\begin{array}{l}41,3714 \\
57,6000\end{array}$ & $\begin{array}{l}12,57235 \\
12,20222\end{array}$ & $-5,480$ & ,000 \\
\hline
\end{tabular}

$\mathrm{P}>0 . \overline{05}$ 
Table 3 shows a statistically significant difference between the pre-test and post-test results of the experimental group students $\quad\left(\mathrm{t}_{(69)}=9.967, \mathrm{p}<0.05\right)$. Experimental group students were found to increase their achievement averages in pre-test results from 42.62 to 71,88. A statistically significant difference was also found between the pre-test and post-test results of the experimental group students $\left(\mathrm{t}_{(69)}=5.480, \mathrm{p}<0.05\right)$. Control group students were found to increase their achievement averages in pre-test results from 41.37 to 57.60 .

\subsection{Permanency Test}

Post-test and permanence test results of experimental and control groups within their own groups are as follows.

Table 4. t-test results of the permanency test of experimental and control groups

\begin{tabular}{|c|c|c|c|c|c|c|}
\hline Tests & Groups & $\begin{array}{l}\text { Number } \\
\text { Students }\end{array}$ & Meaans & $\begin{array}{l}\text { Standard } \\
\text { Deviation }\end{array}$ & $\begin{array}{l}\text { t-test } \\
\text { results }\end{array}$ & Significance \\
\hline EG & $\begin{array}{l}\text { Post-test } \\
\text { Permanency }\end{array}$ & $\begin{array}{l}35 \\
35\end{array}$ & $\begin{array}{l}71,8857 \\
68,6857\end{array}$ & $\begin{array}{l}14,07495 \\
11,74176\end{array}$ & 1,033 & ,305 \\
\hline CG & $\begin{array}{l}\text { Post-test } \\
\text { Permanency }\end{array}$ & $\begin{array}{l}35 \\
35\end{array}$ & $\begin{array}{l}57,6000 \\
50,0571\end{array}$ & $\begin{array}{l}12,20222 \\
10,81922\end{array}$ & 2,736 & ,008 \\
\hline
\end{tabular}

$\mathrm{P}>0.05$

Table 4 gives the results of the post-test at the end of the application and the permanence test administered three weeks after the application. When the permanence results of the experimental group students were examined, no statistically significant difference was found in the permanence of knowledge $(\mathrm{t}(69)=1.033, \mathrm{p}>0.05)$. However, a statistically negative difference was found in control group students $(\mathrm{t}(69)=2.736, \mathrm{p}<0.05)$. Pre-test, post-test and permanence achievement test results of experimental and control groups are also presented in a figure.

\section{$\longrightarrow$ Experiment Group $\square-$ Control Group}

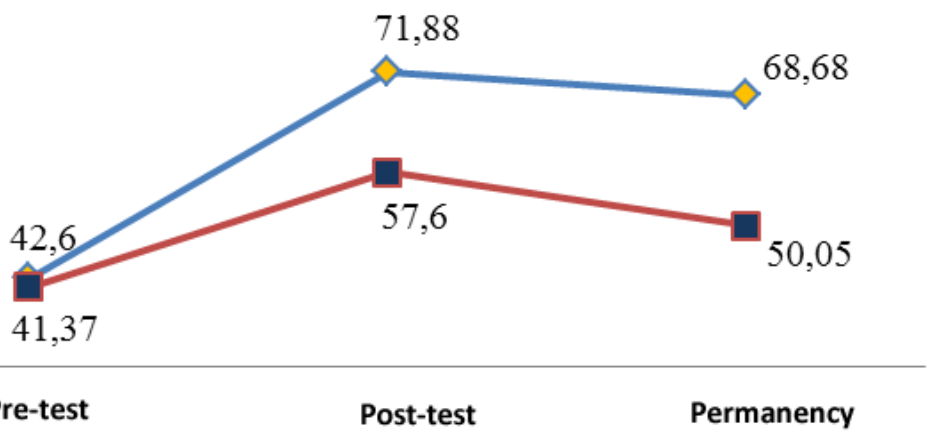

Figrue 3. Achievement score averages of pre-test, post-test and permanence tests of experimental and control groups

It can also be seen from the graph that the achievement level of experimental group students are much higher than those of the control group (Figure 3).

\subsection{Attitude Scale}

The results of the pre-test, post-test and permanency test which were administered to measure the experimental and control group students' attitudes towards science and technology lesson are as follows.

Table 5. t-test results of the pre-test, post-test science and technology lesson attitude scores of experimental and control groups

\begin{tabular}{|c|c|c|c|c|c|c|}
\hline Tests & Groups & $\begin{array}{l}\text { Number of } \\
\text { Students }\end{array}$ & Meaans & $\begin{array}{l}\text { Standard } \\
\text { Deviation }\end{array}$ & t-test results & Significance \\
\hline \multirow{2}{*}{ Pre-test } & EG & 35 & 50,0857 & 12,80940 & \multirow{2}{*}{,- 347} & \multirow{2}{*}{,729 } \\
\hline & CG & 35 & 51,4286 & 18,94308 & & \\
\hline \multirow{2}{*}{ Post-test } & EG & 35 & 51,2857 & 11,39807 & \multirow{2}{*}{,- 262} & \multirow{2}{*}{,794 } \\
\hline & CG & 35 & 52,1429 & 15,63582 & & \\
\hline
\end{tabular}

$\mathrm{P}>0.01$

Table 5 shows no statistically significant difference between the pre-test results of the experimental and control group students' attitudes towards science and technology lesson $\left(\mathrm{t}_{(69)}=0.347, \mathrm{p}>0.05\right)$. No statistically significant difference was found between the post-test results of the experimental and control group students $\left(\mathrm{t}_{(69)}=0.262, \mathrm{p}>0.05\right)$. In 
experimental and control group students, averages for behavior showed differences between groups and within a group.

Table 6. T-test results of the pre-test, post-test science and technology lesson attitude scores of experimental and control groups

\begin{tabular}{|c|c|c|c|c|c|c|}
\hline Tests & Groups & $\begin{array}{ll}\begin{array}{l}\text { Number } \\
\text { Students }\end{array} & \text { of } \\
\end{array}$ & Meaans & $\begin{array}{l}\text { Standard } \\
\text { Deviation }\end{array}$ & $\begin{array}{l}\text { t-test } \\
\text { results }\end{array}$ & Significance \\
\hline \multirow{2}{*}{ EG } & Pre-test & 35 & 50,0857 & 12,80940 & \multirow{2}{*}{,- 414} & \multirow{2}{*}{,680 } \\
\hline & Post-test & 35 & 51,2857 & 11,39807 & & \\
\hline \multirow{2}{*}{ CG } & Pre-test & 35 & 51,4286 & 18,94308 & \multirow{2}{*}{,- 172} & \multirow{2}{*}{, 864 } \\
\hline & Post-test & 35 & 52,1429 & 15,63582 & & \\
\hline
\end{tabular}

$\mathrm{P}>0.01$

Table 6 shows a statistically significant difference between the pre-test and post-test results of the experimental group students $\left(\mathrm{t}_{(69)}=0.414, \mathrm{p}>0.05\right)$. No statistically significant difference was found between the pre-test and post-test results of the experimental group students $\left(\mathrm{t}_{(69)}=0.172\right.$, $\left.\mathrm{p}>0.05\right)$.

Table 7. t-test results of permanency test scores of experimental and control group

\begin{tabular}{|c|c|c|c|c|c|c|}
\hline Tests & Groups & $\begin{array}{l}\text { Number } \\
\text { Students }\end{array}$ & Meaans & $\begin{array}{l}\text { Standard } \\
\text { Deviation }\end{array}$ & t-test results & Significance \\
\hline \multirow[b]{2}{*}{ EG } & Post-test & 35 & 51,2857 & 11,39807 & \multirow[b]{2}{*}{, 230} & \multirow[b]{2}{*}{, 819} \\
\hline & Permanency & 35 & 50,6286 & 12,49020 & & \\
\hline \multirow{2}{*}{$\mathrm{CG}$} & Post-test & 35 & 52,1429 & 15,63582 & \multirow{2}{*}{, 084} & \multirow{2}{*}{,933 } \\
\hline & Permanency & 35 & 51,8000 & 18,41163 & & \\
\hline
\end{tabular}

Table 7 shows the experimental and control group students' results of the post-test at the end of the application and the permanency test administered three weeks after the application. When the permanency test results of the experimental group students are examined, no statistically significant difference can be seen in the permanence of attitude $\left(\mathrm{t}_{(69)}=\right.$ $0.230, \mathrm{p}>0.05)$. No statistically significant difference can be seen in the control group's permanence of attitude $\left(\mathrm{t}_{(69)}=\right.$ $0.084, \mathrm{p}>0.05)$.

The results of experimental and control group students' pre-test, post-test and permanency test are presented in a figure as follows

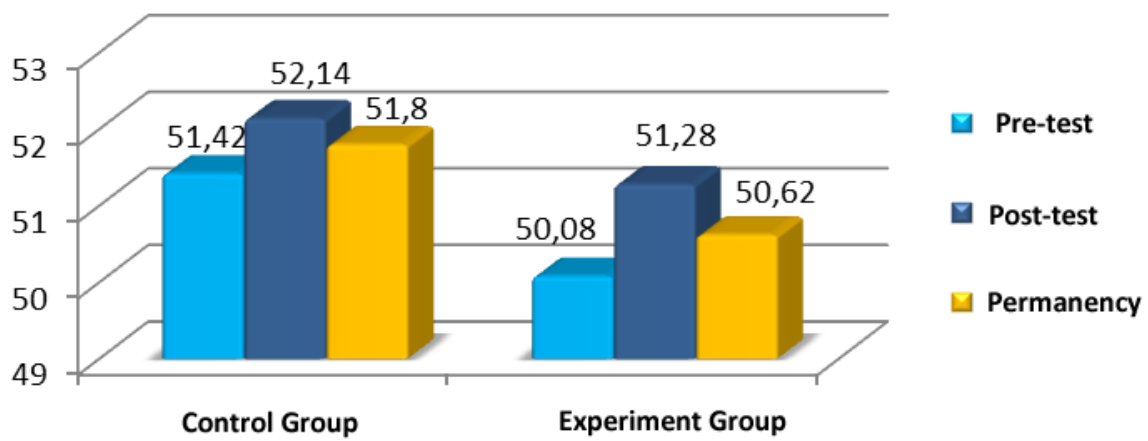

Figure 4. Pre-test, post-test and permanency test attitude score averages of experimental and control groups

Correlation analysis results which compare the experimental and control group students' attitudes towards science and technology lesson and their achievement in systems in our body unit are as follows.

Table 8. Correlation analysis results of experimental group students' academic achievement and their attitudes towards the lesson

\begin{tabular}{clcc}
\hline & & Achievement & Attitute \\
\hline \multirow{2}{*}{ Achievement } & PearsonCorrelation & 1 &, 125 \\
& Sig. (2-tailed) & &, 474 \\
& N & 35 & 35 \\
\multirow{5}{*}{ Attitute } & PearsonCorrelation &, 125 & 1 \\
& Sig. (2-tailed) &, 474 & \\
\hline
\end{tabular}


$\mathrm{N}$

35

35

Correlation analysis results which compare the experimental and control group students' attitudes towards science and technology lesson and their achievement in systems in our body unit are as follows. Table 8 shows no significant association between the achievement and attitudes of the experimental group students $[r(70)=0,125 ; p>0,05]$.

Table 9. Correlation analysis results of control group students' academic achievement and their attitudes towards the lesson.

\begin{tabular}{llll}
\hline & & Achievement & Attitute \\
\hline \multirow{2}{*}{ Achievement } & PearsonCorrelation & 1 &, 490 \\
& Sig. (2-tailed) & &, 778 \\
& N & 35 & 35 \\
Attitute & PearsonCorrelation &, 490 & 1 \\
& Sig. (2-tailed) &, 778 & \\
& N & 35 & 35 \\
\hline
\end{tabular}

Table 9 shows no significant association between the achievement and attitudes of the control group students $[\mathrm{r}(70)=0,490$; $\mathrm{p}>0,05]$.

Pre-test, post-test and permanence test were administered on experimental and control groups in order to examine the effects of web assisted activity based teaching for "systems in our body" unit. Pre-test data analysis shows that when 41,37 average score of control group students was compared with the 42,62 average score of experimental group students, no significant difference was found and the levels of groups were found to be similar to each other ( $\mathrm{t}=0,460$; $\mathrm{p}>0,05)$.

\section{Discussion and Conclusion}

Post-test data analysis of the achievement test shows that control group students form a significant difference with an average of 57,60 when compared with pre-test results $(\mathrm{t}=5,480 ; \mathrm{p}<0.05)$. With 71,88 average post-test score, experimental group students formed a significant difference when compared with pre-test results $(t=9,967 ; p<0,05)$. Both groups are found to increase their success within the group itself. When the increase in achievement scores of experimental and control groups was compared, a significant difference was found in terms of experimental group $(\mathrm{t}=4,53 ; \mathrm{p}<0,05)$.

Considering that both groups are taught with the same physical opportunities, it was concluded that the classes were not adequately equipped with technological materials, and that this kind of environments should be used effectively. With teaching design methods that will enable the use of effective materials being used suitable for constructivist learning, achievement will be increased and meaningful learning will take place. The results of our study showed that web assisted activities of achievement significantly increase students' learning achievement. This result is in parallel with Bayrak Karadeniz and Bayram (2012)'s study in which they found a significant difference in favor of the experimental group in a teaching design assisted by problem based education through web in order to make students learn more meaningfully and more permanently. Our results are also in parallel with Liao and She (2009)'s study in which they examined the conceptual changes and scientific reasoning development of 8 th graders through web based learning method and Barak and Dori (2011)'s study in which they tried to find an answer to the question: "Is an animation worth thousands of visuals?". A great number of studies stating that web assisted studies have a great number of advantages for educators and teachers in science and technology classes also support the results of our study (Bilgi \& Şahin, 2012; Cepni, 2009; Çetinkaya \& Taş, 2011; Gaytan \& McEwen, 2007; Hwang, Wu, \& Chen, 2012)

In the permanence test results which was conducted 3 weeks after the post-test in order to research the permanency of the students' success, post-test average scores of control group students decreased to 50,05 from 57,60. This situation shows that there is a statistically significant negative difference in the control group in terms of permanence group $(t=2,73 ; p<0,05)$. Post-test average scores of experimental group students decreased to 68,68 from 71,88. Although experimental group achievement scores showed a slight decrease, no statistically significant difference was found in the permanence of knowledge $(\mathrm{t}=1,03 ; \mathrm{p}>0,05)$.

The common aspect in the results of recent studies on science and technology is: without suitable knowledge structuring tools, students have difficulties in achieving a permanent learning with the information they learn from books.

In quasi-experimental researches on the effects of computer simulation in science teaching on learning, it has been concluded that computer simulations will, especially as much as laboratory works, contribute to the development of 
traditional education.

When the use of web assisted simulations in science education, the effect of teacher support and the place of lesson programs and web assisted activities are considered, it can be said that these contribute positively to students' success (Rutten, van Joolingen, \& van der Veen, 2012). These results are in parallel with our results.

As well as the positive effects of web assisted studies, Hennessy et al. (2007) also emphasized an important point that by using simulations, teachers moved away from using "real" experiments. This view reveals how important it is to use integrated teaching techniques instead of using only web assisted activities or only simulations. It is thought that such activities will be more suitable to use only when there are conceptual disagreements or when students have difficulties in understanding the subject.

Science and technology attitude scale, which was used to find out how web assisted activity materials affected students' attitudes towards science and technology lesson, was administered on groups as pre-test, post-test and permanency test. The analysis of pre-test data showed that attitude score average of the students in the control group was 51,42 while attitude score average of the students in the experimental group was 50,08 and there was no significant difference between groups in terms of their attitudes towards science and technology lessons and they were similar to each other $(t=0,347 ; p>0,01)$. When the post-test attitude scores of groups were examined, it was found that the students in the control group had an average score of 52,14 while the students in the experimental group had an average score of 51,28. No statistically significant difference was found between groups in terms of their post-test attitude scores $(t=0,262$; $\mathrm{p}>0,01)$. This was an expected outcome due to the fact that the effectiveness was made in a relatively short time. There are many studies that report that attitudes, one of the elements of emotional learning, are difficult to change in the course of a few weeks (Ersoy \& Bayram, 2004; Lim, Lee, \& Grabowski, 2009; Taş, 2006; Çetinkaya \& Taş,2011). In this sense, the findings of the present study are consistent with the results of previous research. Though there seems like no effect on the attitude, there can be in the future because of the experience. It is frequently emphasized by constructivist researches that making direct connections between subject and object is very important. This has a meaning called learning with own first-hand experiences or learning by doing as Dewey (1938) mentioned both.

The analysis of permanency test results which was conducted three weeks after the post-tests in order to find out the permanency of student attitudes showed that average scores of the students in the control group decreased to 51,80 from 52,14 . Average scores of the students in the experimental group also decreased from 51,28 to 50,62. These values show that there was no statistically significant difference in the determination of attitudes $(p>0,01)$.

There are a great number of studies stating that it is very difficult for attitude to change within a period of a few weeks (Çetinkaya \& Taş, 2011; Ercan, Bilen, \& Bulut, 2014; Taş \& Çepni, 2011; Tekin, İnci, Aslan, \& Dursun, 2013). The results of previous studies are in line with our study in terms of this aspect. However, there are also studies which assert that web assisted teaching creates a significant difference in student attitudes (Gül \& Yeşilyurt, 2011). The association between students' attitudes towards science and technology lesson and their success in systems in our body unit was compared and the correlation analysis showed that there was no significant association between groups' attitudes and their success.

Studies show that using web assisted activities facilitate learning. Using these activities irrespective of time and place makes learning easier. When it is taken into consideration that learning and teaching strategies are moving from teacher centered structure to student centered structure, using these kinds of activities in an integrated way in science and technology lessons will increase students' success significantly.

\section{References}

Amadieu, F., Tricot, A., \& Mariné, C. (2010). Interaction between prior knowledge and concept-map structure on hypertext comprehension, coherence of reading orders and disorientation. Interacting with Computers, 22(2), 88-97. http://dx.doi.org/10.1016/j.intcom.2009.07.001

Barak, M., \& Dori, Y. J. (2011). Science Education in Primary Schools: Is An Animation Worth a Thousand Pictures? Journal of Science Education and Technology, 20(5), 608-620. http://dx.doi.org/10.1007/s10956-011-9315-2

Bayrak, Karadeniz, B., \& Bayram, H. (2012). Web Ortamında Probleme Dayalı Öğrenme Yönteminin Farklı Öğrenme Stiline Sahip Öğrencilerin Akademik Başarılarına Etkisi. Mustafa Kemal Üniversitesi Sosyal Bilimler Enstitüsü Dergisi, 9(18), 479-497.

Bilgi, M., \& Şahin, M. (2012). Elementlerde Aktiflik Kavramının Öğretilmesinde Bilgisayar Destekli Öğretim Materyali Kullanılmasının Öğrenci Başarısı Üzerine Etkisi. Türk Fen Eğitimi Dergisi, 9(4), 146-166.

Birgin, O., \& Çathığlu, H. (2009). Book Review: Measurement and assessment. Journal of Turkish Science Education, 6(1), 156-161. 
Çeken, R. (2012) A content Analysis of Elementary Student Projects in terms of Extra-Curricular Biological Knowledge, Necatibey Faculty of Education Electronic. Journal of Science and Mathematics Education,6, 1, , 55-66.

Cepni, S. (2009). Effects of Computer Supported İnstructional Material (CSIM) in Removing Students Misconceptions About Concepts:"Light, Light Source and Seeing”. Energy Educ Sci Technol Part B, 1, 51-83.

Colletta, A. T., \& Chiappetta, E. L. (1989). Science introduction in the middle and secondary schools (second ed.). Ohio, USA: Merrill Publishing Company.

Çetinkaya, M., \& Taş, E. (2011). Canlıların Sınıflandırılması Konusu İçin Web Destekli Kavram Haritaları ve Anlam Çözümleme Tablolarının Öğrenme Üzerindeki Etkisinin Araştırılması. Dicle Üniversitesi Ziya Gökalp Eğitim Fakültesi Dergisi, 16, 180-195.

Dewey, J. (1938). Experience and Education. New York: The Macmillan Company.

Ercan, O., Bilen, K., \& Bulut, A. (2014). The Effect of Web-based Instruction with Educational Animation Content at Sensory Organs Subject on Students' Academic Achievement and Attitudes. Procedia-Social and Behavioral Sciences, 116, 2430-2436. http://dx.doi.org/10.1016/j.sbspro.2014.01.587

Ersoy, N., \& Bayram, H. (2004). Kavram Haritası ve Deney Yönteminin Fen Öğretiminde, Başarıya Etkisi. 6th National Science and Mathematics Education Congress. İstanbul: Book of abstracts, 54.

Ertepınar, H., Demirciog `lu, H., Geban,O־., \& Yavuz, D. (1998). The effect of assimilation and computer based instruction to understand mole concept. III. National Science Education Symposium, Karadeniz Technical University, Turkey.

Erümit, Fiş, S. (2013). Web Tabanlı Uzaktan Eğitimde Biyoloji Dersi için Ders Materyali Tasarımı: Kriterler, Uygulama ve Değerlendirme. Journal of Instructional Technologies \&Teacher Education, 1(2), 86-111.

Francisa, L. J., Katzb, Y. J., Susan, H., \& Jonesc, S. H. (2000). The reliability and validity of the Hebrew version of the Computer Attitude Scale. Computers \& Education, $35, \quad 149-159$. http://dx.doi.org/10.1016/S0360-1315(00)00022-1

Gaytan, J., \& McEwen, B. C. (2007). Effective Online Instructional and Assessment Strategies. The American Journal of Distance Education, 21(3), 117-132. http://dx.doi.org/10.1080/08923640701341653

Gül, Ş., \& Yeşilyurt, S. (2011). The Effect of Computer Assisted Instruction on Fourth Grade Primary Student's Achievements And Attitudes Towards Science And Technology Lesson. e-International Journal of Educational Research, 2(1), 30-43.

Hennessy, S., Wishart, J., Whitelock, D., Deaney, R., Brawn, R., Velle, L., \& Winterbottom, M. (2007). Pedagogical Approaches for Technology-İntegrated Science Teaching. Computers \& Education, 48(1), 137-152. http://dx.doi.org/10.1016/j.compedu.2006.02.004

Hickey, D. T., Ingram-Goble, A. A., \& Jameson, E. M. (2009). Designing Assessments And Assessing Designs in Virtual Educational Environments. Journal of Science Education and Technology, 18(2), 187-208. http://dx.doi.org/10.1007/s10956-008-9143-1

Hwang, G. J., Wu, P.-H., \& Chen, C.-C. (2012). An Online Game Approach for İmproving Students' Learning Performance in Web-Based Problem-Solving Activities. Computers \& Education, 59(4), 1246-1256. http://dx.doi.org/10.1016/j.compedu.2012.05.009

Jang, S. J. (2009). Exploration of Secondary Students' Creativity by İntegrating Web-Based Technology İnto an İnnovative Science Curriculum. Computers \& Education, 52(1), $247-255$. http://dx.doi.org/10.1016/j.compedu.2008.08.002

Liao, Y. W., \& She, H. C., (2009). Enhancing eight grade students' scientific conceptual change and scientific reasoning through a web-based learning program. Educational Technology \& Society, 12(4), 228-240.

Lim, K., Lee, H., \& Grabowski, B. (2009). Does concept-mapping strategy work for everyone? the levels of generativity and learners' self-regulated learning skills. British Journal of Educational Technology, 40(4), 606-618. http://dx.doi.org/10.1111/j.1467-8535.2008.00872.x

Kunduz, N., \& Seçken, N. (2013). Development And Application Of 7E Learnig Model Based Computer-Assisted Teaching Materials On Precipitation Titrations. Journal of Baltic Science Education, 12(6), 784-792.

Liao, Y. W., \& She, H.-C. (2009). Enhancing Eight Grade Students' Scientific Conceptual Change and Scientific Reasoning through a Web-based Learning Program. Journal of Educational Technology \& Society, 12(4). 
MEB, M. E. B. (2006). İlköğretim Fen ve Teknoloji Dersi (6, 7, 8. Sınıflar) Öğretim Programı. MEB, Ankara.

Mitra, A. (1998). Categories of computer use and their relationships with attitudes toward computers. Journal of Research on Computing in Education, 30(3), 281-294.

Rutten, N., van Joolingen, W. R., \& van der Veen, J. T. (2012). The Learning Effects of Computer Simulations in Science Education. Computers \& Education, 58(1), 136-153. http://dx.doi.org/10.1016/j.compedu.2011.07.017

Şahin I. (2007). Assessment of New Turkish Curriculum for Grade 1 to 5. Elementary Education Online, 6(2), 284-304.

Selwyn, N. (1999). Students_attitudes towards computers in sixteen to nineteen education. Education and Information Technologies, 4(2), 129-141. http://dx.doi.org/10.1023/A:1009695816587

Shaw, G., \& Marlow, N. (1999). The role of student learning styles, gender, attitudes and perceptions on information and communication technology assisted learning. Computer \& Education, 33, 223-234. http://dx.doi.org/10.1016/S0360-1315(99)00020-2

Taş, E. (2006). Developing, implementing and evaluating of a web designed science material. Unpublished Doctoral Thesis, Karadeniz Technical University, Turkey.

Tas, E. (2011). A new web designed material approach on learning and assessment in science education. EEST Part B Social and Educational Studies, 3(4), 567-578.

Taş, E., Apaydın, Z., \& Çetinkaya, M. (2011). Research of Efficacy of Web Supported Science and Technology Material Developed With Respect to Constructivist Approach. Energy Educ Sci Technol Part B, 3, 455-468.

Taş, E., Apaydin, Z. \& Çetinkaya, M. (2011). Research of efficacy of web supported science and technology material developed with respect to constructivist approach. Energy Education Science and Technology Part B: Social and Educational Studies, 3(4), 455-468.

Taş, E., \& Çepni, S. (2011). Web Tasarımlı Bir Fen ve Teknoloji Materyalinin Geliştirilmesi, Uygulanması ve Değerlendirilmesi. Pamukkale Üniversitesi Eğitim Fakültesi Dergisi, 24(1), 93-115.

Tekin, N., İnci, T., Aslan, O., \& Dursun, Y. (2013). Fen ve Teknoloji Öğretmen Adaylarının Kavram Haritalarına Yönelik Tutumları ve Kavram Haritası Hazırlayabilme Becerilerinin Çeşitli Değişkenler Açısından İncelenmesi. Ĕgitim Bilimleri Dergisi, 38, 133-148.

Yu, W. F., She, H. C., \& Lee, Y. M. (2010). The Effects of Web - Based/Non - Web - Based Problem - Solving İnstruction and High/Low Achievement on Students' Problem - Solving Ability and Biology Achievement. Innovations in Education and Teaching International, 47(2), 187-199. http://dx.doi.org/10.1080/14703291003718927

This work is licensed under a Creative Commons Attribution 3.0 License. 